\title{
Authentication of cow feeding and geographic origin on milk using visible and near-infrared spectroscopy
}

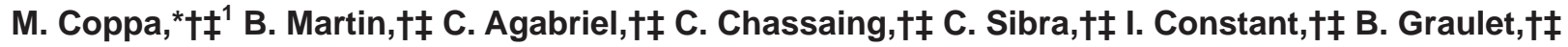 \\ and D. Andueza†‡ \\ *Department AGROSELVITER, University of Turin, Via L. da Vinci 44, 10095, Grugliasco, Italy \\ †INRA, UMR 1213 Herbivores, F-63122 Saint-Genès-Champanelle, France \\ $\neq$ Clermont Université, VetAgro Sup, UMR Herbivores, BP 10448, F-63000 Clermont-Ferrand, France
}

\section{ABSTRACT}

The ability of near-infrared spectroscopy to trace cow feeding systems and farming altitude was tested on 486 bulk milk samples from France and northwestern Italy. Milks were grouped into feeding systems according to the main forage in the diet. Partial least square discriminant analysis correctly classified 95.5, 91.5, and $93.3 \%$ of pasture versus maize silage, hay, and fermented herbage feeding systems, respectively. Discrimination was slightly less successful when diets with large proportions of the nondominant forage were included in each group. Near-infrared spectroscopy correctly discriminated no-pasture from pasture milk, even with only $30 \%$ of pasture in the diet $(5.4 \%$ crossvalidation error), and the error stabilized when pasture exceeded $70 \%$ (2.5\% error). Near-infrared spectroscopy did not reliably trace milk geographic origin when the feeding system effect was isolated from the altitude effect. These findings may be usefully exploited for the authentication of dairy products.

Key words: near-infrared spectroscopy, milk traceability, cow feeding, geographic origin

\section{INTRODUCTION}

In Europe, certification strategies, such as protected designation of origin (PDO) or protected geographical indication (PGI), have been designed to support local producers, especially in marginal areas with high production costs. These certification labels mark out products with high added value and, thus, higher prices, encouraging more frequent counterfeiting. To guarantee the authenticity of certified products for consumers, reliable methods of authentication and traceability are, therefore, required.

Received December 18, 2011.

Accepted June 21, 2012.

${ }^{1}$ Corresponding author: mauro.coppa@unito.it
Many certified dairy production areas are located in upland regions. Upland dairy products are, on average, richer in functional compounds advantageous for human health, such as FA, and in particular $\alpha$-linolenic acid (C18:3n-3; Leiber et al., 2005; Lucas et al., 2006), branched-chain FA, rumenic acid (cis-9,trans-11 C18:2; Collomb et al., 2002), and plant secondary metabolites with anti-oxidative properties (e.g., terpenes; Tornambé et al., 2006; Revello Chion et al., 2010) and polyphenols (Besle et al., 2010).

Several studies have focused on the traceability of upland dairy products to distinguish them from those produced in lowland areas. Engel et al. (2007) found that terpenes, vitamins $\mathrm{A}$ and $\mathrm{E}$, and carotenoids could help to authenticate upland milk production (vs. lowland). However, FA were the most reliable tracers. Similarly, De Noni and Battelli (2008) identified terpene and FA profiles as potential tracers of upland origin in Bitto cheese.

The useful results previously reported for upland product discrimination are not directly linked to altitude itself but rely on the specific upland feeding strategies based on the extensive use of grasslands for animal feeding. Cropping (e.g., maize) is, in general, marginal, and environmental conditions associated with pasture agronomic practices are responsible for the specific botanical composition of grasslands. These specific features are known to strongly influence milk composition. Dairy product contents in FA, terpenes, polyphenols, and carotenoids are also strongly influenced by animal feeding (Dewhurst et al., 2006; Engel et al., 2007; Besle et al., 2010). Compared with maize silage, grass-fed cows produce milk with lower levels of SFA, and higher levels of PUFA (Ferlay et al., 2008; Morales-Almaráz et al., 2010, 2011). Also, fresh herbage in the cow diet increases contents of $\beta$-carotene and vitamins A and E in milk (Nozière et al., 2006). Highly biodiverse pastures, rich in dicotyledons, have also been shown to give milk with higher concentrations of PUFA and, in particular, C18:3n-3 (Tornambé et al., 2010; Coppa et al., 2011b). 
The analytical reference methods for the assay of such milk constituents, useful for geographic origin or animal feeding traceability, involve lengthy work-up, including solvent extraction and derivation, followed by analysis by gas GC or HPLC, and so are generally expensive and time consuming. Their use in routine analysis for dairy product authentication is, thus, impracticable. Near-infrared reflectance spectroscopy (NIRS), which is nondestructive, rapid, cheap, and multiparametric, is a candidate alternative technique to collect information on animal diet and milk origin. Also, its ability to predict FA profile and carotenoid content in dairy products has been demonstrated (Lucas et al., 2008a,b; Coppa et al., 2010). For authentication purposes, González-Martín et al. (2011) successfully applied NIRS on cheese to recognize its production season, which involves changes in animal feeding, and Karoui et al. (2005) were able to trace the geographic origin of Emmental cheese. Martin et al. (2006) successfully applied NIRS technology to the authentication of milk geographic origin (lowland vs. upland). However, their experimental design might have masked a feeding system effect beneath the altitude effect.

The aim of this work was to distinguish bulk milk according to (1) the main cow feeding system; (2) the dominant forage in the cow diet, irrespective of altitude; and (3) geographic origin (lowland vs. upland), avoiding combined effects of cow feeding, using NIRS. Particular attention was paid to the effect of fresh herbage proportion in cow diets on discrimination results, and to the authentication of the milk from alpine pasture.

\section{MATERIALS AND METHODS}

\section{Milk Sampling and Survey}

Four hundred eighty-six bulk cow milk samples was collected from 172 farms in France and northwestern Italy during 2007 and 2008. The farms were selected to cover a wide variety of milk production conditions, cow breeds, and altitude range $[0$ to $2,430 \mathrm{~m}$ above sea level (a.s.l.)]. In each farm, milk samples (about $400 \mathrm{~mL}$ each) were collected several times to explore the seasonal variation in animal feeding, increasing sampling frequency for those farms practicing transhumance, thus changing pasture altitude and vegetation type. During sample collection, data on farming conditions and animal feeding were recorded by on-farm surveys, according to Agabriel et al. (2004). Surveys included questions about altitude, forage management (forage characteristics, forage harvesting and storage, and cutting and grazing periods), and animal feeding during the indoor period or during pasture exploitation. Special attention was paid to forage (maize or grass), grasslands, and their exploitation or preservation modes (pasture, hay, silage, or haylage). Pasture intake was estimated by difference between the energy requirements of the herd and the energy provided by the known quantities of feeds offered in the diet. The energy balance was supposed equal to zero. The animal requirements and the energy value of each feed were attributed according to the Institut National de la Recherche Agronomique (INRA) tables (Faverdin et al., 2007).

\section{Milk Grouping Criteria}

Milk samples were assigned to groups according to various criteria based on production conditions. The main characteristics of each group are reported in Table 1.

Cow Feeding System. To define the main cow feeding systems, a hierarchical cluster analysis was performed on survey data on the proportion of different feedings in cow diet. Milks were classified into 4 main groups according to forage. The first group $(\mathbf{H})$ comprised milk samples derived from diets with, on average, $69 \%$ of the average total DM daily intake as hay. The second group (FH) comprised milk samples derived from diets in which fermented herbage (grass silage or haylage) was, on average, $60 \%$ of total DM daily intake. The third (MS) and the fourth (P) groups included diets with, on average, $49 \%$ maize silage and $75 \%$ fresh herbage, respectively. However, cutting the cluster dendrogram at a different level, the P and MS groups were divided into 2 subgroups each: the main one comprising diets with a small proportion of feed differing from the main forage of the main group, the other, smaller one comprising milk samples with mixed diets including a low proportion of the dominant forage. Only the first 2 main groups, (noted Ps and MSs, respectively) were retained for subsequent statistical analysis. The MSs cluster grouped samples with, on average, $56 \%$ maize silage in the cow diet, reducing from 43 and $45 \%$ to 18 and $30 \%$ the maximum proportion of pasture and fermented forages in the group, respectively, compared with the MS group. The Ps cluster grouped samples with a lower maximum proportion of fermented forages and concentrates than the P group (from 47 and $48 \%$ to 25 and $36 \%$, respectively; Table 1).

Dominant Forage in the Cow Diet. To make diet more homogeneous within each group classified by the cluster analysis, milks with more than $55 \%$ of the main feed in the group were selected (MS $>55 \%, \mathrm{H}>55 \%$, and $\mathrm{P}>55 \%$ for maize silage, hay, and pasture, respectively). The average proportion of the dominant forage rose to 63,73 , and $82 \%$ for $\mathrm{MS}>55 \%, \mathrm{H}>55 \%$, and $\mathrm{P}$ $>55 \%$ groups, respectively (Table 1 ). 
Table 1. Production condition of milk sample groups within the calibration sets: average value and minimum and maximum values (in parentheses)

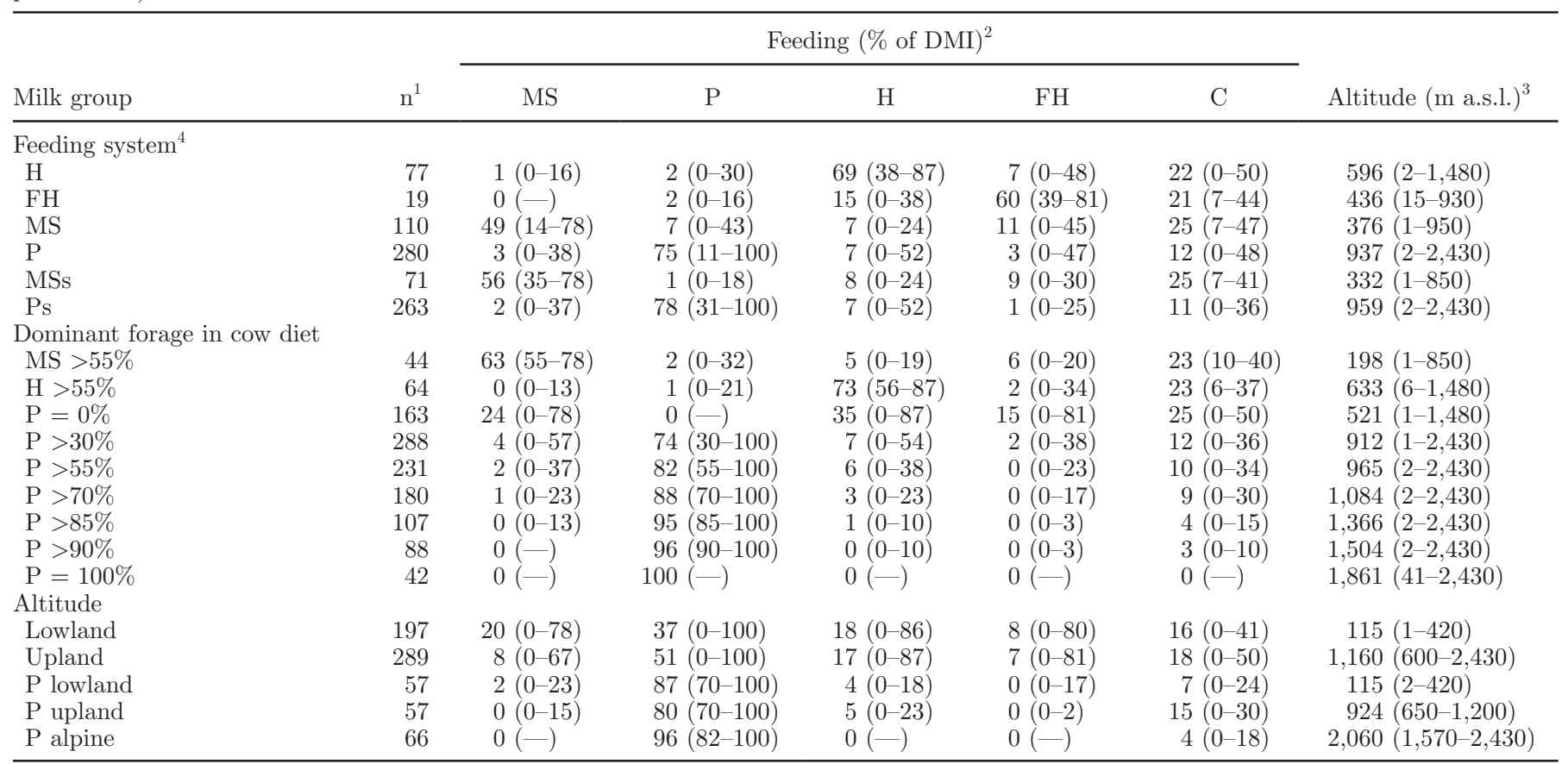

${ }^{1}$ Number of milk samples.

${ }^{2} \mathrm{MS}=$ maize silage; $\mathrm{P}=$ pasture $\mathrm{H}=$ hay; $\mathrm{FH}=$ fermented herbage; $\mathrm{C}=$ concentrates.

${ }^{3}$ a.s.l. = above sea level.

${ }^{4} \mathrm{MSs}=$ maize silage subgroup with low proportion of mixed diets; Ps = pasture subgroup with low proportion of mixed diets.

Finally, to evaluate the effect of different proportions of fresh herbage in cow diet on the reliability of milk traceability using NIRS, milk samples were grouped on the basis of minimum pasture percentage in the cow diet, into $\mathrm{P}=0 \%, \mathrm{P}>30 \%, \mathrm{P}>55 \%, \mathrm{P}>70 \%$, $\mathrm{P}>85 \%, \mathrm{P}>90 \%$, and $\mathrm{P}=100 \%$ of the average total DMI, irrespective of the results of the cluster analysis. The characteristics of each group are reported in Table 1.

Altitude. Milks produced below or above $600 \mathrm{~m}$ a.s.l. were assigned to the lowland and upland group, respectively. The proportion of the different forages fed to animals ranged from 0 to $78 \%$ and from 0 to $67 \%$ of the average total DM daily intake for maize silage for the lowland and upland groups, respectively (Table 1), and from 0 to $100 \%$ for pasture of both altitude groups. Similarly, the proportion of hay ranged from 0 to $86 \%$ and from 0 to $87 \%$ and the proportion of fermented herbage from 0 to $80 \%$ and from 0 to $81 \%$. Finally, the proportion of concentrate ranged from 0 to $41 \%$ and from 0 to $50 \%$ for the lowland and upland groups, respectively (Table 1 ).

To test the ability of NIRS to authenticate milk originating from lowland, upland, or alpine pasture, milk samples derived from pasture providing at least
$70 \%$ of average total DMI were divided according to altitude into lowland (below $600 \mathrm{~m}$ a.s.l.), upland (from 600 to $1,200 \mathrm{~m}$ a.s.l.) and alpine pasture (above 1,200 $\mathrm{m}$ a.s.l.) (Table 1). The 3 groups reflected altituderelated changes in agronomic practices and grazing management and, consequently, in pasture botanical composition. In the lowland group, the temporary intensively managed grasslands formed the dominant forage, whereas in the upland group, the intensification of agronomical practices was lower and pastures were mainly permanent, with a consequent increase in grassland species richness. Alpine meadows were only permanent pastures, heterogeneous and highly biodiversified, and extensively managed.

\section{Analysis}

Bulk milk samples were collected on farm, kept at $4^{\circ} \mathrm{C}$, and transported to the laboratory where they were immediately frozen and stored at $-18^{\circ} \mathrm{C}$ until analysis. Before analysis, each sample was left for $2 \mathrm{~h}$ at room temperature, and then $0.5 \mathrm{~mL}$ of milk was placed on the internal part of a 55-mm glass microfiber filter (Whatman GF/A, 55 mm, catalog no. 1820 055; Whatman International Ltd., Maidstone, UK), and oven-dried at 
$40^{\circ} \mathrm{C}$ for $24 \mathrm{~h}$. Each filter was then placed in a $50-\mathrm{mm}-$ diameter ring cup after cutting the external part of microfiber filter and scanned at 2-nm intervals from 400 to $2,498 \mathrm{~nm}$ using a Foss NIRSystems model 6500 NIRS scanning spectrometer (Foss NIRSystems, Silver Spring, MD). The NIRS spectrometer was controlled with ISIscan software version 2.21 (Infrasoft International LLC, State College, PA). Each reflectance spectrum was averaged from 32 scans and compared with the average of 32 measurements of a ceramic reference. The absorbance was recorded as $\log (1 / R$, where $R=$ reflectance). The segment between $400 \mathrm{~nm}$ and 2,500 $\mathrm{nm}$ was used. The standard normal variate and detrend scatter correction procedure (Barnes et al., 1989) was applied to the raw data. The spectra were then transformed using a mathematical first-order gap derivation $(1,4,4,1$, where the first digit is the number of the derivative, the second is the gap over which the derivative is calculated, the third is the number of data points in the first smoothing, and the fourth is the number of data points in the second smoothing). To highlight the absorbance bands with the chemical composition of milk samples, the average raw spectrum of each group was transformed by a second-order gap derivative $(2,10,10,1)$. The difference between the transformed average spectra of each couple of compared groups was then calculated.

\section{Statistics}

A hierarchical cluster analysis with the average linkage method between groups and Pearson correlation proximity index was performed on cow feeding data derived from the surveys. Cluster analysis was performed with the SPSS for Windows software package (version 16.0; SPSS Inc., Chicago, IL).

Discriminant analysis between the groups described above was performed using the partial least squares discriminant analysis technique, and models were tested using a cross-validation procedure. Six cross-validation randomly chosen groups were used at each discrimination. No outlier elimination passes were allowed. WinISI II version 1.60 software (Infrasoft International LLC) was used. For the discriminations having an error in cross-validation lower than $10 \%$, an external validation was tested. A pool of 80 samples was then extracted from the original groups according to the proportion of these groups in the total population constituting the validation set. For instance, being 70 the number of samples in group A and 30 the number of samples in group B of the calibration sets, the validation groups comprised $70 \%$ of samples extracted from group A and the $30 \%$ from group B. To make the validation data set completely independent, all milk samples taken from the same farm were included in the validation set. A new calibration was then performed with the remaining samples and the models were validated with the validation set. The characteristics of the groups used for the external validation are reported in Table 2 . The external validation was not tested for those comparisons involving the FH feeding system, because of the low number of samples included in the $\mathrm{FH}$ group.

\section{RESULTS AND DISCUSSION}

\section{Ability of NIRS to Trace Animal Feeding Systems and Dominant Forage}

The range and mean values for each milk samples group were similar within the calibration and validation sets (Tables 1 and 2). The results of discriminant analysis performed to test the ability of NIRS to trace cow feeding systems from milk samples are reported in Table 3.

Recently, NIRS has been successfully used on ewe milk to trace animal feeding (Mouazen et al., 2009), differentiating pasture from box feeding. However, to our knowledge, it has never been applied to feeding traceability of cow milk collected in ordinary farming conditions.

The results of the present study show that NIRS responses for discriminating MS from $\mathrm{P}$ feeding systems were promising $(92.3 \%$ of milk correctly classified in cross-validation, and $96.2 \%$ in external validation; Table 3). The lower external validation error compared with the cross-validation one, could be due to the narrower range of production conditions characterizing the milk samples from the farms constituting the validation set (Tables 1 and 2). The error was reduced when discriminating MSs versus Ps (95.5\% of samples correctly classified in cross-validation, and $94.9 \%$ in external validation), because of the lower frequency of mixed diets within each group. The discrimination reliability was improved again when comparing groups in which pasture or maize silage accounted for at least half of the DMI ( $\mathrm{P}>55 \%$ vs. MS $>55 \%$ ), with $96.4 \%$ of correctly classified milk in cross-validation, and $96.3 \%$ in external validation. This result may be mainly linked to the reduced presence of mixed diets with a minimal pasture proportion. Comparing milk derived from diets without pasture $(\mathrm{P}=0 \%)$ with those composed of more than $30 \%$ of pasture $(\mathrm{P}>30 \%)$, only $5.9 \%$ of milk samples were misclassified in cross-validation (Figure 1). Also, NIRS ability for discriminating between no-pasture (P $=0 \%$ ) and pasture milk increased when the proportion of fresh herbage in the cow diet increased (5.0 and 2.9\% of error in cross-validation, respectively, for $\mathrm{P}>55 \%$ and $\mathrm{P}>70 \%$; Figure 1). 
Table 2. Production condition of milk sample groups within the validation sets: average value and minimum and maximum values (in parentheses)

\begin{tabular}{|c|c|c|c|c|c|c|c|}
\hline Milk group & $\mathrm{n}^{1}$ & \multicolumn{5}{|c|}{ Feeding $(\% \text { of DMI })^{2}$} & Altitude (m a.s.l. $)^{3}$ \\
\hline \multicolumn{8}{|c|}{ Feeding system ${ }^{4}$} \\
\hline $\mathrm{H}$ & 18 & $1(0-13)$ & $3(0-20)$ & $74(63-86)$ & $0(0-0)$ & $22(10-37)$ & $610(6-1,400)$ \\
\hline MS & 20 & $49(27-67)$ & $4(0-31)$ & $6(0-15)$ & $10(0-32)$ & $31(23-41)$ & $362(40-815)$ \\
\hline $\mathrm{P}$ & 60 & $3(0-37)$ & $75(31-100)$ & $6(0-52)$ & $3(0-35)$ & $14(0-36)$ & $1,064(65-2,430)$ \\
\hline MSs & 17 & $52(39-73)$ & $1(0-13)$ & $6(0-15)$ & $9(0-20)$ & $30(23-41)$ & $325(40-850)$ \\
\hline $\mathrm{MS}>55 \%$ & 13 & $64(57-73)$ & $2(0-32)$ & $6(0-15)$ & $6(0-19)$ & $22(10-29)$ & $191(40-820)$ \\
\hline$H>55 \%$ & 17 & $1(0-13)$ & $0(0-0)$ & $75(63-86)$ & $0(0-0)$ & $25(14-37)$ & $605(6-1,200)$ \\
\hline $\mathrm{P}>55 \%$ & 67 & $2(0-30)$ & $81(57-100)$ & $6(0-30)$ & $0(0-0)$ & $10(0-24)$ & $784(16-2,230)$ \\
\hline
\end{tabular}

${ }^{1}$ Number of milk samples.

${ }^{2} \mathrm{MS}=$ maize silage $\mathrm{P}=$ pasture $\mathrm{H}=$ hay $; \mathrm{FH}=$ fermented herbage $\mathrm{C}=$ concentrates.

a.s.l. = above sea level.

${ }^{4} \mathrm{MSs}=$ maize silage subgroup with low proportion of mixed diets; Ps = pasture subgroup with low proportion of mixed diets.

Comparing the average second-order derivative milk spectra difference between $\mathrm{P}>70 \%$ and $\mathrm{P}=0 \%$ (Figure 2), the greatest differences were found at around 400 to 700,904 to $1,066,1,682$ to $1,772,2,008$ to 2,094 , and 2,146 to $2,370 \mathrm{~nm}$. Prominent peaks of spectra $(400-700 \mathrm{~nm})$ can be related to the absorption of carotenoids (Prache et al., 2002); maxima at 904, 1,720, $1,758,2,196,2,296$, and $2,334 \mathrm{~nm}$ can be related to $\mathrm{C}-\mathrm{H}$ bond absorption of oils and proteins; and maxima at 2,076 and 2,376 $\mathrm{nm}$ to the absorption of $\mathrm{O}-\mathrm{H}$ and $\mathrm{C}-\mathrm{C}$ bonds of lipids, respectively (Osborne and Fearn, 1998). These peaks may result from the differences induced in milk carotenoids and FA concentrations by pasture or preserved forage diets. It has been demonstrated that pasture feeding increases milk carotenoid content (Nozière et al., 2006), fresh herbage being richer in $\beta$-carotenes than preserved forages. Pasture milk is, thus, yellower (Engel et al., 2007). Also, Lucas et al. (2008b) were able to reliably predict $\beta$-carotene and yellowness of cheeses with NIRS, suggesting that these 2 variables could contribute to milk discrimination by NIRS. Similarly, pasture feeding profoundly changes milk fat composition, increasing the concentration of PUFA, in particular cis-9,trans-11 conjugated linoleic acid, and C18:3n-3, and of MUFA, in particular cis-9 C18:1 and trans-11 C18:1, with a consequent reduc-

Table 3. Results of discriminant analysis performed on milk samples to trace cow feeding system, dominant forage in cow diet, and geographic origin

\begin{tabular}{|c|c|c|c|c|}
\hline Item & $\mathrm{n}^{1}$ & $\begin{array}{c}\text { Milk samples } \\
\text { correctly classified }\end{array}$ & $\begin{array}{l}\text { Error (\%) in } \\
\text { cross-validation }\end{array}$ & $\begin{array}{l}\text { Error }(\%) \text { in } \\
\text { external validation }\end{array}$ \\
\hline \multicolumn{5}{|l|}{ Altitude $^{2}$} \\
\hline Lowland vs. upland & 486 & 367 & 24.5 & \\
\hline \multicolumn{5}{|l|}{ Feeding system ${ }^{3}$} \\
\hline MS vs. P & 390 & 360 & 7.7 & 3.8 \\
\hline MSs vs. Ps & 334 & 319 & 4.5 & 5.1 \\
\hline MSs vs. FH & 93 & 82 & 11.8 & \\
\hline $\mathrm{H}$ vs. $\mathrm{FH}$ & 96 & 82 & 14.6 & \\
\hline \multicolumn{5}{|c|}{ Dominant forage in cow $\operatorname{diet}^{4}(\%$ on total DMI) } \\
\hline $\mathrm{P}>55 \%$ vs. $\mathrm{MS}>55 \%$ & 275 & 265 & 3.6 & 3.7 \\
\hline $\mathrm{P}>55 \%$ vs. $\mathrm{H}>55 \%$ & 295 & 272 & 7.8 & 4.9 \\
\hline MS $>55 \%$ vs. $\mathrm{H}>55 \%$ & 108 & 83 & 23.1 & \\
\hline
\end{tabular}

${ }^{1}$ Number of milk samples.

${ }^{2} \mathrm{P}=$ pasture.

${ }^{3} \mathrm{MS}=$ maize silage system; MSs = maize silage subgroup with low proportion of mixed diets; P = pasture system; Ps = pasture subgroup with low proportion of mixed diets; $\mathrm{H}=$ hay system; $\mathrm{FH}=$ fermented herbage system.

${ }^{4} \mathrm{MS}=$ maize silage; $\mathrm{H}=$ hay. 


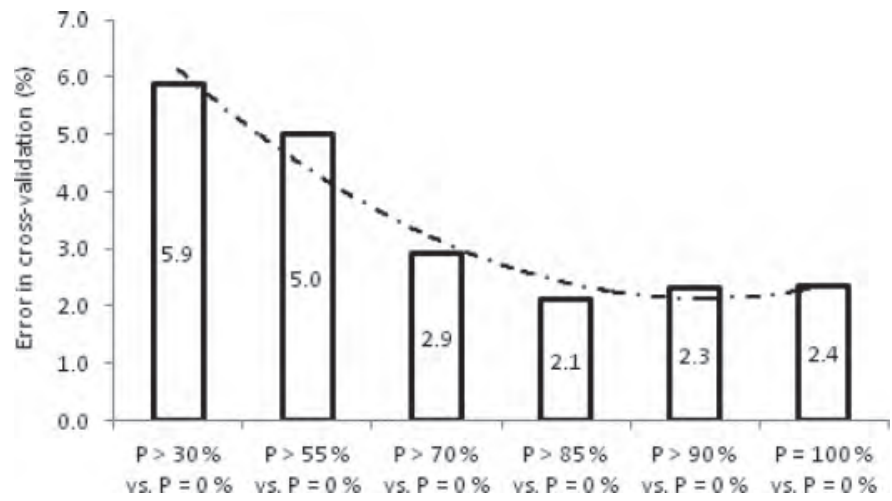

Figure 1. Decreasing trend of cross-validation error when discriminating milk derived from diet with no pasture $(\mathrm{P}=0 \%)$ and diet with increasing minimal proportions of pasture $(30,55,70,85,90$, and $100 \%)$.

tion in SFA (Chilliard et al., 2007; Morales-Almaráz et al., 2010, 2011). Near-infrared reflectance spectroscopy sensitivity in milk FA prediction has also been demonstrated (Coppa et al., 2010).

The error in discriminating between no-pasture $(\mathrm{P}=$ $0 \%$ ) and pasture-derived milk tended to become stable with a pasture proportion in the diet higher than $70 \%$ ( $\mathrm{P}>70 \%$; Figure 1). Above this proportion of fresh herbage in cow diet, the differences in milk composition become minimal and depend mainly on herbage quality: botanical composition, phenological stage, and grazing management (Collomb et al., 2002; Tornambé et al., 2010; Coppa et al., 2011b). For instance, the richness in C18:3n-3, cis-9,trans-11 conjugated linoleic acid, and PUFA, in general, in milk from highly biodiversified pasture exploitation has been demonstrated (Collomb et al., 2002; Leiber et al., 2005). However, it was associated with a lower concentration of carotenoids (Tornambé et al., 2010). Similarly, a decrease in milk carotenoid content when cows graze mature herbage rather than herbage at the vegetative stage have been associated with a parallel decrease in herbage $\beta$-carotene content during aging (Nozière et al., 2006). A full grazing system, with around $100 \%$ of average cow daily DMI, is mainly based on the exploitation of extensive pasture, which is usually highly biodiverse and grazed at a more developed phenological stage. Comparing the spectral difference between $\mathrm{P}=100 \%$ and $\mathrm{P}=0 \%$ with those between $\mathrm{P}>70 \%$ and $\mathrm{P}=0 \%$ milk groups, narrower gaps in the visible band related to carotenoids (Prache et al., 2002) and a wider gap in the band of the absorption of different bonds related to lipids (Osborne and Fearn, 1998) have been observed (Figure 2).

The discrimination results for Ps versus preserved herbage feeding systems ( $\mathrm{H}$ or $\mathrm{FH}$ ) were promising (Table 3). As expected, however, the proportion of correctly classified milk samples in cross-validation was slightly lower than those obtained when comparing

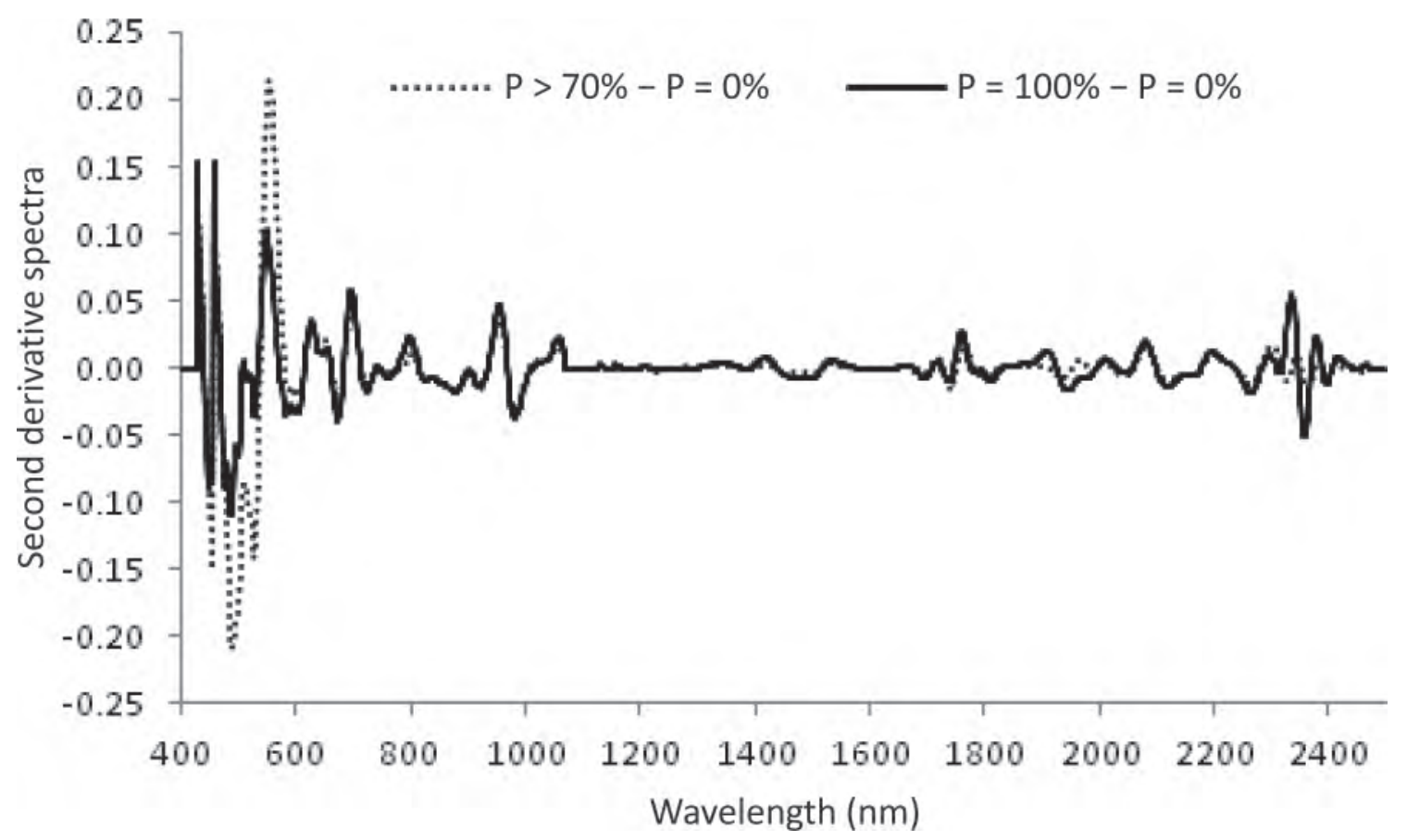

Figure 2. Differences between the average second-order derivative spectra of pasture higher than $70 \%$ average cow daily DMI (P $>70 \%)$ and with no pasture $(\mathrm{P}=0 \%)$ milk sample groups, and between $100 \%$ pasture $(\mathrm{P}=100 \%)$ and no pasture $(\mathrm{P}=0 \%)$ milk sample groups. 
pasture- with maize silage-based diets $(91.5 \%$ for Ps vs. $\mathrm{H}, 93.3 \%$ for Ps vs. FH, and $92.2 \%$ for $\mathrm{P}>55 \%$ vs. $\mathrm{H}>55 \%)$. Results of external validation also agreed with those in cross-validation (Table 3). Fatty acid and carotenoid compositions of maize silage-derived milk have been shown to be more extreme than those of preserved herbage-derived milk, compared with pasture milk (Chilliard et al., 2007; Engel et al., 2007).

The cross-validation error increased in the discrimination among milks derived from preserved forage feeding: only $79.7,88.2,85.4$, and $76.9 \%$ of samples were correctly classified for MSs versus $\mathrm{H}$, MSs versus $\mathrm{FH}, \mathrm{H}$ versus $\mathrm{FH}$, and $\mathrm{MS}>55 \%$ versus $\mathrm{H}>55 \%$, respectively (Table 3). Again, differences in FA profiles among milks from different preserved forages were significantly smaller than those between preserved forage- and pasture-derived milk (Ferlay et al., 2006).

\section{Ability of NIRS to Trace Geographic Origin of Milk Production}

A novel finding in this study is the similarity of cow diets between upland and lowland groups: grouping milk only on the basis of altitude, the average proportion of each feeding pattern was well-balanced between the 2 groups, with equivalent minima and maxima. This homogeneity enabled us to test the altitude effect with no confounding effect of animal feeding. In our trial, NIRS failed reliably to trace milk geographic origin (lowland vs. upland), showing only $75.5 \%$ of correctly classified samples (Table 3). Even if these results disagree with literature data, they are not unexpected. Martin et al. (2006), successfully discriminated upland from lowland milk samples using NIRS. However, the lowland milk derived mainly from maize silage and temporary grassland (fresh or preserved), whereas the upland milk derived from grass-based feeding: grazing on permanent pastures in summer and hay- or grass silage-based diets in winter. This lowland versus upland discrimination may have been mainly related to differences in milk composition due to cow feeding, as discussed by those authors. Similarly, Karoui et al. (2005) successfully discriminated different types of Emmental cheese according to origin. Although they gave only little information on cow feeding, the different production areas may have involved different feeding practices, at least for the PDO Gruyère cheese, which was successfully discriminated from the PDO L'Etivaz cheese, whose production specifications restrict its production during summer, with milk derived only from uplands.

In our trial, NIRS also failed to trace altitude sensu stricto within the pasture-derived milk (only $62.2 \%$ of correctly classified samples for P lowland vs. P upland vs. $\mathrm{P}$ alpine; Table 3 ). The reduced differences in milk composition deriving from the altitude-related changes in vegetation types, compared with those among different feeding systems, were probably responsible for the low reliability of this prediction. Differences in FA profile according to vegetation altitude are mainly related to C18:3n-3 and branched-chain FA, which have higher concentrations in upland milk, and especially in alpine milk (Leiber et al., 2005; Engel et al., 2007). These FA were not satisfactorily predicted by NIRS (Coppa et al., 2010). Also, fresh herbage $\beta$-carotene, giving milk a yellow color, which influences the visible part of NIRS spectra, is also less influenced by botanical composition than by sward phenology (Tornambé et al., 2010), depending on the grazing management, and only slightly on vegetation type (Coppa et al., 2011a). In addition, Engel et al. (2007) found milk color ineffective in discriminating between lowland and upland milk.

\section{CONCLUSIONS}

The low classification error confirms that NIRS can correctly discriminate between bulk milk from feeding systems based on pasture or on preserved forages. The reliability of the discrimination results depends mainly on the proportion of fresh herbage in the cow diet, giving promising results on mixed diets, even with a low pasture proportion, and being stable when over $70 \%$. These results may prove useful for the authentication of those dairy products whose production specifications delimit animal feeding. By contrast, in our study, NIRS was not powerful enough to trace milk geographic origin reliably, suggesting that NIRS results are more closely related to the diet of cows than to the altitude effect itself.

\section{ACKNOWLEDGMENTS}

This work was supported by the "Traditional United Europe Food" (TRUEFOOD) project, an integrated project financed by the European Commission under the Sixth Framework Programme for RTD (contract no. FOOD-CT-2006-016264).

\section{REFERENCES}

Agabriel, C., B. Martin, C. Sibra, J. C. Bonnefoy, M. C. Montel, R. Didienne, and S. Hulin. 2004. Effect of dairy production system on the sensory characteristics of Cantal cheeses: A plant-scale study. Anim. Res. 53:221-234.

Barnes, R. J., M. S. Dhanoa, and S. J. Lister. 1989. Standard normal variate transformation and de-trending of near infrared diffuse reflectance spectra. Appl. Spectrosc. 43:772-777.

Besle, J. M., D. Viala, B. Martin, P. Pradel, B. Meunier, J. L. Berdagué, D. Fraisse, J. L. Lamaison, and J. B. Coulon. 2010. Ultraviolet-absorbing compounds in milk are related to forage polyphenols. J. Dairy Sci. 93:2846-2856. 
Chilliard, Y., F. Glasser, A. Ferlay, L. Bernard, J. Rouel, and M. Doreau. 2007. Diet, rumen biohydrogenation and nutritional quality of cow and goat milk fat. Eur. J. Lipid Sci. Technol. 109:828855.

Collomb, M., U. Bütikofer, R. Sieber, B. Jeangros, and J.-O. Bosset. 2002. Correlations between fatty acids in cows' milk fat produced in the lowland, mountain and highlands of Switzerland and botanical composition of the fodder. Int. Dairy J. 12:661-666.

Coppa, M., A. Farruggia, P. Pradel, G. Lombardi, and B. Martin. 2011a. An improved grazed class method to estimate species selection and dry matter intake by cows at pasture. Ital. J. Anim. Sci. $10: 58-65$.

Coppa, M., A. Ferlay, C. Leroux, M. Jestin, Y. Chilliard, B. Martin, and D. Andueza. 2010. Prediction of milk fatty acid composition by near infrared reflectance spectroscopy. Int. Dairy J. 20:182189.

Coppa, M., A. Ferlay, F. Monsallier, I. Verdier-Metz, P. Pradel, R. Didienne, A. Farruggia, M. C. Montel, and B. Martin. 2011b. Milk fatty acid composition and cheese texture and appearance from cows fed hay or different grazing systems on upland pastures. J. Dairy Sci. 94:1132-1145.

De Noni, I., and G. Battelli. 2008. Terpenes and fatty acids of milk fat and "Bitto" cheese as affected by transhumance of cows in different mountain pastures. Food Chem. 109:299-309.

Dewhurst, R. J., K. J. Shingfield, M. R. F. Lee, and N. D. Scollan. 2006. Increasing the concentrations of beneficial polyunsaturated fatty acids in milk produced by dairy cows in high-forage systems. Anim. Feed Sci. Technol. 131:168-206.

Engel, E., A. Ferlay, A. Cornu, Y. Chilliard, C. Agabriel, G. Bielicki, and B. Martin. 2007. Relevance of isotopic and molecular biomarkers for the authentication of milk according to production zone and type of feeding. J. Agric. Food Chem. 55:9099-9108.

Faverdin, P., R. Delagarde, L. Delaby, and F. Mechy. 2007. Alimentation des vaches laitières. Pages 23-55 in Alimentation des bovins, ovins et caprins. Besoins des animaux-Valeurs des aliments. Tables INRA 2007. Éditions Quae, Versailles, France.

Ferlay, A., C. Agabriel, C. Sibra, C. Journal, B. Martin, and Y. Chilliard. 2008. Tanker milk variability in fatty acids according to farm feeding and husbandry practices in a French semi-mountain area. Dairy Sci. Technol. 88:193-215.

Ferlay, A., B. Martin, P. Pradel, J. B. Coulon, and Y. Chilliard. 2006. Influence of grass-based diets on milk fatty acid composition and milk lipolytic system in Tarentaise and Montbéliarde cow breeds. J. Dairy Sci. 89:4026-4041.

González-Martín, I., J. M. Hernández-Hierro, J. Salvador-Esteban, C. González-Pérez, I. Revilla, and A. Vivar-Quintana. 2011. Discrimination of seasonality in cheese by near-infrared technology. J. Sci. Food Agric. 91:1064-1069.

Karoui, R., É. Dufour, L. Pillonel, E. Schaller, D. Picque, T. Cattenoz, and J.-O. Bosset. 2005. The potential of combined infrared and fluorescence spectroscopies as a method of determination of the geographic origin of Emmental Cheese. Int. Dairy J. 15:287-298.

Leiber, F., M. Kreuzer, D. Nigg, H. R. Wettstein, and M. R. L. Scheeder. 2005. A study on the causes for the elevated n-3 fatty acids in cows' milk of Alpine origin. Lipids 40:191-202.

Lucas, A., C. Agabriel, B. Martin, A. Ferlay, I. Verdier-Metz, J.-B. Coulon, and E. Rock. 2006. Relationships between the conditions of cow's milk production and the contents of components of nutritional interest in raw milk farmhouse cheese. Lait 86:177-202.

Lucas, A., D. Andueza, A. Ferlay, and B. Martin. 2008a. Prediction of fatty acid composition of fresh and freeze-dried cheeses by visiblenear-infrared reflectance spectroscopy. Int. Dairy J. 18:595-604.

Lucas, A., D. Andueza, E. Rock, and B. Martin. 2008b. Prediction of dry matter, fat, $\mathrm{pH}$, vitamins, minerals, carotenoids, total antioxidant capacity, and color in fresh and freeze-dried cheeses by visible-near-infrared reflectance spectroscopy. J. Agric. Food Chem. 56:6801-6808.

Martin, B., M. Jestin, I. Constant, C. Agabriel, and D. Andueza. 2006 Authentification de la zone de production de laits de grand mélange (plaine-montagne) à partir de méthodes spectrales dans le visible et le proche infrarouge. Page 194 in Rencontres Recherches Ruminants. Vol 13. INRA and Institut de l'Elevage, Paris, France.

Morales-Almaráz, E., B. de la Roza-Delgado, A. González, A. Soldado, M. L. Rodríguez, M. Peláez, and F. Vicente. 2011. Effect of feeding system on unsaturated fatty acid level in milk of dairy cows. Renewable Agric. Food Syst. 26:224-229.

Morales-Almaráz, E., A. Soldado, A. González, A. Martínez-Fernández, I. Domínguez-Vara, B. de la Roza-Delgado, and F. Vicente. 2010. Improving the fatty acid profile of dairy cow milk by combining grazing with feeding of total mixed ration. J. Dairy Res. $77: 225-230$.

Mouazen, A. M., S. Dridi, J. De Baerdemaeker, and H. Ramon. 2009. Prediction of selected ewe's milk properties and differentiating between pasture and box feeding using visible and near infrared spectroscopy. Biosystems Eng. 104:353-361.

Nozière, P., B. Graulet, A. Lucas, B. Martin, P. Grolier, and M. Doreau. 2006. Carotenoids for ruminants: From forages to dairy products. Anim. Feed Sci. Technol. 131:418-450.

Osborne, B. G., and T. Fearn. 1998. Near infrared spectroscopy in food analysis. Longman Scientific \& Technical, Essex, UK.

Prache, S., A. Priolo, H. Tournadre, L. Jailler, H. Dubroeucq, D. Micol, and B. Martin. 2002. Traceability of grass-feeding by quantifying the signature of carotenoid pigments in herbivores meat, milk and cheese. Pages 592-953 in Multi-Function Grassland: Quality Forages, Animal Products and Landscapes. Grassland Science in Europe. Vol. 7. J. L. Durand, J. C. Emile, C. Huyghe, and G. Lemaire, ed. Association Française pour la Production Fourragère, Versailles cedex, France.

Revello Chion, A., E. Tabacco, D. Giaccone, P. G. Peiretti, G. Battelli, and G. Borreani. 2010. Variation of fatty acid and terpene profile in mountain milk and "Toma Piemontese" cheese as affected by diet composition in different seasons. Food Chem. 121:393-399.

Tornambé, G., A. Cornu, P. Pradel, N. Kondjoyan, A. P. Carnat, M. Petit, and B. Martin. 2006. Changes in terpene content in milk from pasture-fed cows. J. Dairy Sci. 89:2309-2319.

Tornambé, G., A. Ferlay, A. Farruggia, Y. Chilliard, P. Loiseau, P. Pradel, B. Graulet, B. Chaveau-Duriot, and B. Martin. 2010. Influence of botanical diversity and development stage of mountain pastures on milk fatty acid composition, carotenoids, fat-soluble vitamins and sensory properties. Pages 589-591 in Grassland in a Changing World. Grassland Science in Europe. Vol. 15. H. Schnyder, J. Isselstein, E. Taube, K. Auerswald, J. Schellberg, M. Wachendorf, A. Herrmann, M. Gierus, N. Wrage, and A. Hopkins, ed. Universität Göttingen, Göttingen, Germany. 